\title{
Pleural Mesothelioma pNO TNM Finding v7
}

National Cancer Institute

\section{Source}

National Cancer Institute. Pleural Mesothelioma pNO TNM Finding v7. NCI Thesaurus. Code $C 88908$.

Pleural mesothelioma with no regional lymph nodes metastases. (from AJCC 7th Ed.) 